\title{
DAMPAK PENGGUNAAN GADGET TERHADAP PERKEMBANGAN ANAK USIA DINI DI PAUD DAN TK TARUNA ISLAM PEKANBARU
}

\author{
Ns. Fitra Mayenti, S. Kep, M. Kep*, Indiana Sunita, SKM, M. Kes** \\ Staf Dosen STIKes Al-Insyirah Pekanbaru \\ E-mail : fitramayenti19@gmail.com
}

\begin{abstract}
Abstrak
Latar Belakang :Gadget memiliki berbagai fitur dan aplikasi menarik, bervariasi, interaktif dan fleksibel sehingga menambah daya tarik bagi setiap orang, baik dari kalangan lansia, muda, remaja bahkan anak-anak. Gadget memiliki banyak manfaat dalam kehidupan manusia jika digunakan dengan baik dan tepat, tetapi gadged juga memberikan dampak negative bagi manusia khususnya bagi perkembangan anak jika digunakan tanpa pengawasan dan pengarahan dari orang tua. Tujuan penelitian ini untuk mengidentifikasi dampak penggunaan Gadget terhadap Perkembangan anak usia dini di PAUD dan TK Taruna Islam Pekanbaru. Metode : Desain penelitian ini adalah kuantitatif dengan metode analisis deskriptif untuk menemukan atau menjelaskan peristiwa kejadian yang terjadi pada masa sekarang serta memperoleh gambaran empirik tentang dampak penggunaan gadged terhadap anak usia dini. Hasil : Hasil penelitian didapatkan 48,3\% Gadget berdampak negative dan $57 \%$ Perkembangan anak sesuai. Hasil uji statistik menunjukkan tidak ada hubungan antara penggunaan gadget dengan perkembangan anak dengan $p$-value 0,60. Saran : diharapkan orang tua agar memberikan pengawasan yang tepat terhadap anak dalam penggunaan gadget
\end{abstract}

Kata kunci : Gadget, Perkembangan Balita

\begin{abstract}
Background: Gadgets have various interesting, varied, interactive and flexible features and applications that add to the appeal for everyone, both among the elderly, young, teenagers and even children. Gadgets have many benefits in human life if they are used properly and correctly, but gadged also has a negative impact on humans, especially for the development of children if used without supervision and direction from parents. The purpose of this study was to identify the impact of the use of Gadgets on Early Childhood Development in PAUD and Pekanbaru Taruna Islam Kindergarten. Method: The design of this study is quantitative with descriptive analysis methods to find or explain events that occur in the present and obtain an empirical picture of the impact of gadged use on early childhood. Results: The results of the study were $48.3 \%$ of the gadgets had a negative impact and 57\% of children's development was appropriate. Statistical test results showed no relationship between gadget usage and the development of children with p-value 0,60. Suggestion: parents are expected to provide proper supervision of children in the use of gadgets.
\end{abstract}

Keyword : Gadget, toddler development 


\section{LATAR BELAKANG}

Abad ke 21 merupakan masa dimana Ilmu Pengetahuan dan Teknologi (IPTEK) mengalami perkembangan yang sangat pesat, terutama dibidang alat komunikasi. Berawal dari surat dan telepon kabel, kini telah berkembang menjadi handphone, laptop, tablet, ipad, android dan lain sebagainya atau yang lebih dikenat dengan gadged.

Gadget adalah alat elektronik yang memiliki pembaharuan dari hari ke hari sehingga membuat hidup manusia lebih praktis. Beberapa tahun yang lalu gadget hanya banyak di pakai oleh para pembisnis dari kalangan menangah ke atas.Alasan mereka menggunakan gadget adalah untuk memudahkan bisnis mereka. Namun pada zaman sekarang, gadget tidak hanya dipakai oleh para pembisnis saja, akan tetapi wajib dimiliki siapa saja mulai dari usia lansia, dewasa, remaja bahkan anakanak yang seharusnya belum layak mengguankannya, hal ini di sebabkan gadged memiliki berbagai fitur dan aplikasi yang menarik, bervariasi, interaktif, fleksibel sehingga menambah daya tarik.

Anak-anak kini telah menjadi konsumen aktif dimana banyak produkproduk elektronik dan gadget yang menjadikan anak-anak sebagai target pasar mereka. Dalam penelitan Syifa Ameliola, dkk (2010) dikutip pada New York Times, sebuah kasus terjadi dimana seorang anak cendrung pada iPad. Anak tersebt harus merengek ketika gadget kesayangan itu tidak berada dalam genggaman tangannya. Anak ini dapat dikatakan telah mengalami ketergantungan terhadap salah satu terobosan terbaru pada era globalisasi ini. Pada saat makan, saat belajar, saat bermain, bahkan saat tidur tidak dapat lepas dari gadget tersebut. Orang tua tidak dapat melakukan banyak hal selain menuruti keinginan anak tersebut. Pada hakikatnya, anak-anak belum saatnya mengenal gadget, mereka masih memerlukan interaksi yang lebih luas dengan crayon, buku gambar, temanteman bermain, dan lain sebagainya

Gadget memiliki pengaruh besar terhadap kehidupan manusia, demikian pula terhadap anak-anak. Dari segi psikologis, masa kanak-kanak adalah masa keemasan dimana anak-anak belajar mengetahuiapa yang belum diketahuinya. Jika masa kanak-kanak sudah mencandu dan terkena dampak negatif oleh gadget, maka perkembangan anakpun akan terhambat, karena pengalaman masa kecil mempunyai pengaruh yang kuat terhadap perkembangan berikutnya. Selain itu, tanpa disadari anak sering menerapkan "What You See is What You Get". Penerapan ini memiliki makna apa yang dilihat oleh anak adalah sebuah pelajaran, apa bila tanpa bimbingan yang terarah dan terpadu dari orang tua dan keluarga, perkembangan anak akan mengarah pada sisi negatif. Oleh karena itu, orang tua dituntut lebih kreatif dalam mendidik anak, menyediakan sarana bermain, belajar dan media lainnya yang lebih sehat dan sesuai dengan masa tumbuh kembang anak mereka, terutama di masa emas anak usia dini, sebab peran orang tua sangat penting dalam perkembangan teknologi terhadap anak, orang tua harus cermat dan membimbing anak dalam penggunaan gadged, karena fasilitas yang disediakan oleh gadget tidak hanya menimbulkan dampak positif tetapi juga dapat menimbulkan dampak negatif. Sedangkah usai dini merupakan tahap perkembangan dari kecerdasan motorik, kecerdasan 
berfikir, kecerdasan emosional, bahasa serta komunikasi ini menunjukan bahwa anak usia dini adalah aset masa depan suatu bangsa yang harus diperhatikan dalam setiap tahap masa perkembangan.

Bedasarkan survei awal di Paud dan TK Taruna Islam, di dapatkan jumlah siswa/i keseluruhan 74 orang, dengan jumlah masing-masing untuk Paud 12 orang dan TK 62 orang, dan dari hasil wawancara dengan seluruh siswa/i Paud dan TK Taruna Islam sebanya 74 orang tersebut telah mengenal gadged dan memilikinya.

Berdasarkan latar belakang diatas peneliti tertarik untuk melakuan penelitian tentang Dampak penggunaan gadged terhadap perkembangan anak usia dini di Paud (Pendidikan usia dini) dan TK (Taman Kanak-kanak) Taruna Islam Pekanbaru.

\section{METODE PENELITIAN}

Pendekatan yang dilakukan dalam penelitian ini adalah kuantitatif dengan pendekatan Cross sectional dimana penelitian variabel independen dan dependen dilakukan secara bersamaan. Penelitian dilaksanakan di Paud dan TK Islam Pekanbaru. Instrumen penelitian menggunakan kuesioner yang berisi tentang perkembangan anak, dampak penggunaan gadget dan pengawasan orang tua.

\section{HASIL DAN PEMBAHASAN}

Tabel 1. Distribusi Karakteristik Responden di TK dan PAUD Taruna Islam Pekanbaru Tahun 2016

\begin{tabular}{llcc}
\hline Karakteristik Responden & \multicolumn{1}{c}{ Kategori } & f & \% \\
\hline 1. Usia Orang Tua & Dewasa akhir & 28 & 46.7 \\
& Dewasa awal & 32 & 53.3 \\
2. Pendidikan Orang Tua & Tinggi & 23 & 38.3 \\
& Rendah & 37 & 61.7 \\
3. Jenis Kelamin & Laki-laki & 31 & 52.5 \\
& Perempuan & 28 & 47.5 \\
4. Lama & Lama & 22 & 36.7 \\
Gadget & Tidak Lama & 38 & 63.3 \\
5. Jenis Permainan & Nonton & 3 & 5 \\
& Games & 19 & 63.3 \\
& Belajar Sambil Bermain & 31.7 \\
\hline
\end{tabular}

Berdasarkan tabel 1 menunjukkan dari 60 responden, usia orangtua sebagian besar berusia dewasa awal yaitu 32 orang $(53,3 \%)$ dan kurang dari sebgaian 28 orang $(46,7 \%)$ dewasa akhir.Pendidikan orang tua lebih dari sebagian 37 orang $(61,7 \%)$ berpendidikan rendah dan pendidikan tinggi kurang dari sebagian 33 orang $(38,3 \%)$. Usia anak lebih dari sebagian 34 orang $(56.7 \%)$ usia pra sekolah dan kurang dari sebagian 26 $(43,3 \%)$ usia sekolah. Jenis kelamin responden lebih dari sebagian 31 orang $(52,5 \%)$ dan 28 orang $(47,5 \%)$. 
Tabel 2. Distribusi Dampak Penggunaan Gadget di TK dan PAUD Taruna Islam Pekanbaru Tahun 2016

\begin{tabular}{lcc}
\hline \multicolumn{1}{c}{$\begin{array}{c}\text { Dampak } \\
\text { Penggunaan } \\
\quad \text { Gadget }\end{array}$} & f & \% \\
\hline Positif & 31 & 51.7 \\
Negatif & 29 & 48.3 \\
Total & $\mathbf{6 0}$ & $\mathbf{1 0 0}$ \\
\hline
\end{tabular}

Berdasarkan tabel 2 menunjukkan dari 60 responden 31 orang $(51,7 \%)$ dampak penggunaan Gadget adalah positif, dampak positif yang terlihat pada anak dalam bentuk anak mudah memperoleh informasi terkait pendidikan seperti mengenal warna dan bahasa, hal ini juga anak lebih kreatif, serta aktif sekolah dan di lingkungan tempat tinggal, sedangkan 29 orang $(48,3 \%)$ dampak penggunaan gadget adalah negatif, ini terlihat anakanak lebih cenderung mudah marahl, hiperaktif dan suka merebut permainan teman-temannya, Dampak negatif lainnya yang ditimbulkan anak lebih cepat beradaptasi dengan teknologi, sehingga anak-anak terlena dengan kecanggihan teknologi, lupa dengan lingkungan sekitarnya, lebih memilih bermain gadget dibandingkan bermain bersama temanteman serta lingkungan sekitar tempat tinggalnya.Sehingga komunikasi sosial antara anak dengan masyarakat berkurang bahkan semakin luntur.

Tabel 3. Perkembangan anak di TK dan PAUD Taruna Islam Kota Pekanbaru Tahun 2016

\begin{tabular}{lcc}
\hline $\begin{array}{l}\text { Perkembangan } \\
\text { Anak }\end{array}$ & $\mathbf{f}$ & \% \\
\hline Sesuai & 57 & 95 \\
Tidak Sesuai & 3 & 5 \\
$\quad$ Total & $\mathbf{6 0}$ & $\mathbf{1 0 0}$ \\
\hline
\end{tabular}

Tabel 3 menunjukan persentase perkembangan anak di TK dan Paud Taruna Islama sesuai dengan usianya sebesar 95 persen lebih besar dari perkembangan anak yang tidak sesuai dengan usianya yaitu 5 persen. Hal ini menunjukan bahwa anak TK dan Paud Taruna Islam perkembangannya sesuai usia sudah sangat baik, akan tetapi masih ada sebagian kecil anak-anak yang mengalami gangguan perkembangan sesuai dengan usia anak.

Tabel 4. Dampak Penggunaan Gadget terhadap perkembangan anak di TK dan PAUD Taruna Islama Kota Pekanbaru Tahun 2016

\begin{tabular}{lccccccc}
\hline Dampak & \multicolumn{3}{c}{ Perkembangan Anak } & Total & $\begin{array}{c}\text { P } \\
\text { Venggunaan } \\
\text { Gadget }\end{array}$ & Sesuai & \multicolumn{5}{c}{ Tidak Sesuai } \\
& F & $\%$ & F & $\%$ & f & $\%$ & \\
& & & & & & & \\
Positif & 30 & 96.8 & 1 & 3.2 & 31 & 100 & 0.60 \\
Negatif & 27 & 93.1 & 2 & 6.9 & 29 & 100 & \\
Total & $\mathbf{5 7}$ & & $\mathbf{3}$ & & $\mathbf{6 0}$ & & \\
\hline
\end{tabular}


Dari tabel 4 dapat dilihat bahwa dampak positif penggunaan gadget terhadap perkembangan anak yang sesuai dengan usia anak adalah $96,8 \%$ dan yang tidak sesuai sebesar 3,2\%, sedangkan untuk dampak negative penggunan gadgetterhadap perkembangan anak yang sesuai dengan usia anak yaitu $93,1 \%$ dan yang tidak sesuai $6,9 \%$.

Hasil uji statistik didapatkan nilai $p=0,60$ lebih besar dari 0,05 artinya tidak ada hubungan yang signifikan antara dampak penggunaan gadget dengan perekmbangan anak, berbeda dengan penelitian Muhammad Fuad Efendi (2014) melaporkan bahwa bahwa ada pengaruh gadget terhadap perkembangan anak. Hal ini disebabkan karena anak-anak di TK taruna dalam penggunaa Gadget mayoritas kurang dari 2 jam dan masih terkontrol dan juga letak geografis dari responden yang berada ditengah-tengah kota Pekanbaru, akses dari segala informasi mudah didapat, sehingga informasi yang berhubungan dengan bahaya penggunaan gadge tmudah didapatkan sehingga tidak berdampak terhadap perkembangan anak.

Gadget berpotensi membuat anak cepat puas dengan pengetahuan yang diperolehnya sehingga menganggap apa yang didapatnya dari internet atau teknologi lain adalah pengetahuan yang terlengkap dan final (Ratih Ibrahim, 2012). Pada faktanya ada begitu banyak hal yang harus digali lewat proses pembelajaran tradisional dan internet tidak bisa menggantikan kedalaman suatu pengetahuan. Kalau tidak dicermati, maka akan ada kecenderungan bagi generasi mendatang untuk menjadi generasi yang cepat puas dan cenderung berpikir dangkal.
Kemajuan teknologi yang membawa banyak kemudahan, generasi mendatang berpotensi untuk menjadi generasi yang tidak tahan dengan kesulitan. Dengan kata lain, anak akan berpikir atau merasa bahwa hidup ini seharusnya mudah dan pada akhirnya anak berusaha untuk menyederhanakan masalah dan berupaya menghindari kesukaran.

Kemajuan teknologi mempercepat segalanya dan tanpa disadari anak pun dikondisikan untuk tidak tahan dengan keterlambatan.Hasilnya anak makin hari makin lemah dalam hal kesabaran serta konsentrasi dan cepat menuntut orang untuk memberi yang diinginkannya dengan segera.

Romo (2013), menurutnya bermain gadget dalam durasi yang panjang dan dilakukan setiap hari secara kontinyu, bisa membuat anak berkembang ke arah pribadi yang antisosial. Ini terjadi karena anakanak ini tidak diperkenalkan untuk bersosialisasi dengan orang lain. Selain itu juga berpotensi mendorong anak untuk menjalin relasi secara dangkal.Waktu untuk bercengkerama secara langsung berkurang karena sekarang waktu tersita untuk menikmati semuanya dalam kesendirian. Hasil observasi yang dilakukan Anggrahini (2013) kepada beberapa keluarga di salah satu daerah wilayah Yogyakarta menunjukan sejak menggunakan gatget, ketika di rumah anak menjadi susah diajak berkomunikasi, tidak peduli dan kurang berespon pada saat orang tua mengajaknya berbicara.

\section{SARAN}

1. Perlu dilakukan penelitian lebih lanjut mengenai dampak penggunaan gadget terhadap perkembangan anak focus pada psikososial anak.terhadap 
2. Mengingat penelitian ini belum dilakukan secara kualitatif, maka diharapkan kepada peneliti selanjutnya untuk dapat menemukan informasi langsung baik kepada orang tua, guru maupun murid.

3. Sekolah juga memiliki peran dalam mendidik anak, maka kepada pihak sekolah agar dapat memberikan pengarahan kepada anak-anak tentang bahaya gadget serta aturan dalam penggunaannya, mengingat semua ucapan guru lebih didengar dan dipahami oleh anak-anak

4. Diharapkan adanya kerja sama antara pihak sekolah dengan pihak orang tua untuk saling berkolaborasi dalam mengawasi perkembangan anak.

\section{DAFTAR PUSTAKA}

Beauty, Yudi, Franly. 2015. Hubungan penggunaan gadged dengan tingkat prestasi siswa di sma negeri 9 manado (ejournak keperawatan (eKep) Volume 3. Nomor 2). Manado : Program Studi Ilmu Keperawatan Fakultas Kedokteran, Universitas Sam Ratulangi

Depkes RI. 2009. Prinsip pengelolaan program KIA. Jakarta

Fitria, Sainah. 2013. Pengaruh penggunaan teknologi komputer terhadap anak usia dini, diunduh pada 1 November 2015.

Iis, Hendra, Edy, 2014. Pengaruh penggunaan gadged terhadap daya kembang anak (Prosiding Seminar Nasional Multidisiplin Ilmu). Jakarta : Universitas Budi Luhur
Muh F. 2013. Pengaruh gadged terhadap perkembangan anak usia dini. Surabaya : Teknik Informatika, Universitas Brawijaya PTIIK

Octaviani H, 2013. Menelisik pengaruh penggunaan aplikasi gadged terhadap perkembangan psikologi anak usia dini (Karya Tulis Ilmiah). Semarang : Fakultas Ilmu Pendidikan, Universitas Negeri Semarang

Syifa, Hanggara, 2010. Perkembangan media informasi dan teknologi terhadap anak dalam era globalisasi. Malang : Fakultas Pertanian, Universitas Brawijaya

Anggrahini, 2013. Dinamika komunikasi keluarga penggna gadget, Universitas Ilsma Negeri Sunan Kalijaga, Fakultas Ilmu Sosial dan Humaniora. Yogyakarta.

Karman. 2013. Riset penggunaan media dan pengembangannya kini. Jurnal Studi Komunikasi dan Media, Vol 17, No.1

Yulia Trinika. 2015. Pengaruh penggunaan gadget terhadap perkembangan psikologi anak usia prasekolah (3-6 tahun) di TK Swasta Kristen Immanuel Tahun Ajaran 2014-2015

Syaiful Bahri Djamarah, 2004. Pola komunikasi orang tua dan anak dalam keluarga. Bandung: CV. Pustaka Setia, hal : 2-3.

Elly M, Setiadi, dkk. 2011. Pengantar sosiologi. Jakarta: Kencana

Dwi Narwoko, dkk, 2011. Sosiologi teks pengantar dan terapan. Jakarta : Kencana 